\title{
Risk Factors Associated with Type 2 Diabetes Mellitus in Adolescents
}

\author{
Factores de Riesgo asociados a la Diabetes Mellitus Tipo 2 en Adolescentes
}

\author{
Zayda Arlette Trejo Osti ${ }^{a}$, Jorge Abelardo Falcón Lezama ${ }^{b}$
}

\begin{abstract}
:
Despite T2DM is considered a nosological entity of adults, it has increased in children under 19 years old. This is due to changes in lifestyles but above all to the increase of overweight and obesity registered in recent years. There are multiple studies focused on describing both the epidemiology and the clinical presentation of T2DM in children and adolescents. In Mexico, there is little research that provides data on the behavior and distribution of this disease in the Mexican population. However, given the characteristics of the population, it is very likely to find more cases than those that are currently reported. That is why this article aims at making a brief analysis of the main risk factors associated with diabetes, epidemiology, physiopathology, clinical presentation as well as diagnosis and treatment in T2DM in adolescents.
\end{abstract}

\section{Keywords:}

Adolescents, Diabetes type 2, Risk Factors

\section{Resumen:}

Aunque la DM2 se considera una entidad nosológica propia de los adultos, se ha registrado un incremento de la misma en menores de 19 años; esto debido a los cambios en los estilos de vida pero sobre todo al incremento del sobrepeso y obesidad registrados en los últimos años. A nivel mundial existen múltiples estudios enfocados en describir tanto la epidemiología como la presentación clínica de la DM2 en niños y adolescentes; en México es escasa la investigación que aporten datos sobre el comportamiento y la distribución de esta enfermedad en población mexicana. Sin embargo, y dadas las características propias de la población, es muy probable encontrar más casos de los reportados actualmente. Es por ello que el presente artículo pretende hacer un breve análisis de los principales factores de riesgo asociados a la diabetes, epidemiología, fisiopatología, presentación clínica así como diagnóstico y tratamiento en la DM2 en adolescentes.

\section{Palabras Clave:}

Adolescentes, Diabetes tipo 2, Factores de Riesgo

\section{INTRODUCTION}

In general, Type 2 Diabetes (T2DM) is defined as a hyperglycemia resulting from the imbalance between the production of insulin and the inadequate response of the organism to it. ${ }^{1}$ It has always been considered a disease that mainly affects adults; while Type 1 Diabetes is associated with pediatric ages, although this is not always the case. Around the world there has been an increase in obesity in young people, the main factor associated with the genesis of T2DM. This behavior has been seen globally; in fact, the prevalence of overweight and obesity in children under 5 years old has experienced an important increase from $4.2 \%$ in 1990 to $6.7 \%$ in 2010 . If this continues, it is expected that by the year 2020 , the prevalence will increase to $9.1 \% .^{1,2}$ The development of diabetes is mainly associated with two factors: lifestyle and genetics. The study conducted in 2013, "genetic interaction and lifestyle: the study in the Pima Indians of Mexico and the Pima Indians of the United States"; 3 corroborates the influence of lifestyle over genetics, and that by making a modification in the first one, the onset of diabetes at any age can be prevented. On the other hand, it is important to note that screening the entire adolescent population is not cost-effective ${ }^{4}$ that is why, when performing the analysis of the associated factors, it will allow the clinician to have the skills to timely detect the development of the disease and therefore improve the quality of life of individuals. This is

${ }^{a}$ Universidad Autónoma del Estado de Hidalgo, Health Sciences Institute, Email: Zayda_trejo@uaeh.edu.mx

${ }^{b}$ Corresponding author. Fundación Carlos Slim 
the key to all the programs and projects that have been carried out over the last few years to achieve a change in the lifestyles of Mexicans of all ages. The aim of this article is to describe in a general way the main risks associated with the development of T2DM, as well as the diagnostic criteria and treatment in adolescent patients.

\section{MAIN RISCK FACTORS}

As mentioned above, the factors associated with the genesis of diabetes have different effects on the life and health of the individual and although each of them is important, there are some that have greater value than others.

\section{Overweight, obesity and insulin resistance}

Overweight and obesity are defined as an abnormal or excessive accumulation of fat..$^{5}$ The World Health Organization (WHO) classifies "overweight as the Body Mass Index (BMI) by age with more than one standard deviation above the median established in childhood growth patterns, and obesity is higher than two standard deviations above the median established in the WHO child growth patterns. ${ }^{6}$ Overweight and obesity are multifactorial conditions resulting from the imbalance between the contribution and expenditure of energy; when the carbohydrate intake exceeds the requirements, it is stored in the form of adipose tissue. Excess weight is in itself a sufficient cause for presenting an insulin resistance and those patients with a normal BMI are very likely to have a predominantly abdominal fat distribution. ${ }^{7}$

Obesity and overweight are associated with the insulin resistance syndrome. This effect can be explained by a decrease in the sensitivity of the hormone that generates as response the increase of its secretion. The organism manages to maintain this balance for some time until the homeostatic mechanisms fail, leading to an increase in blood glucose and finally to metabolic failure. All this translates clinically into the onset of Type 2 Diabetes or the metabolic syndrome. ${ }^{4}$

Several authors confirm that the majority of patients are obese or extremely obese at the time of diagnosis. ${ }^{8-11}$ It highlights the important relationship between the increase in Type 2 Diabetes and morbid obesity, especially in the most susceptible populations. ${ }^{12}$ A study conducted in Latin American population showed that young people with T2DM presented an average of $32.8 \mathrm{~kg} / \mathrm{m} 2 \mathrm{BMI}$ at the time of diagnosis. ${ }^{13}$ While CaballeroNoguez et al., in 2016, determined a strong association between overweight and obesity with insulin resistance in Mexican children. $^{14}$

In Mexico, between 1988 and 2012, the prevalence of obesity in adolescents between 12 and 19 years old increased from 11.1 to $35.5 \%$ in women, while in men it was from 33 to $34.1 \%$. This increase was calculated with data obtained from 2006 and 2012. ${ }^{13}$ The final report of the mid-way 2016 National Health and Nutrition Survey found a prevalence of obesity and overweight of $36.3 \%$ in adolescents aged 12 to 19 years, $1.4 \%$ higher than in $2012 .^{15}$

\section{Physical activity and eating habits}

The WHO defines physical activity as "any body movement produced by skeletal muscles that requires energy expenditure" and recommends that children and young people from 5 to 17 years old perform at least 60 minutes of moderate to intense daily exercise, or at least three times a week. ${ }^{16}$ Despite the total population between 10 to 14 years old, only $17.2 \%$ perform at least 60 minutes of moderate-vigorous activity 7 days a week; while in the group of 15 to 19 years old it increased from $56.7 \%$ to $60.5 \%$ from 2012 to 2016 . In both groups it is noted that physical activity is higher in men than in women. ${ }^{17}$

The energy requirements of adolescents are higher compared to adults because factors such as growth, sex, physical activity among others; they influence the demand of metabolism. According to the dietary and physical activity guidelines for the Mexican population, it is suggested to make three main meals a day with two intermediate snacks; have a specific schedule in addition to promoting active participation of adolescents in the choice of menus. ${ }^{18}$ According to a study carried out in 2015, young people who had a normal BMI (43.2\%) always had their three meals, while those who did not had a BMI between overweight and obesity. ${ }^{19}$ It is logical to think that having an adequate and sufficient diet is a protective factor for the development of overweight and obesity. However, due to the different lifestyles, it is increasingly common that these three times are not performed and rarely occur in the family. On the other hand, it is imperative to monitor risky behaviors such as alcoholism, smoking and eating behaviors. ${ }^{18}$

\section{Genetic factors}

Recent studies in multiple human populations have identified alleles of disease risk that are common in one population but rare in others. In 2014, the SIGMA Diabetes type 2 Consortium analyzed 9.2 million single nucleotide polymorphisms (SNP) in 8,214 Mexicans and other Latin Americans: 3,848 with Type 2 Diabetes and 4,366 non-diabetic controls. They identified a novel locus associated with Type 2 Diabetes at the genomic level that encompasses the solute carriers SLC16A11 and SLC16A13P. ${ }^{20}$

According to the obtained results, it was found that the association was stronger in younger and thinner people with Type 2 Diabetes and they were replicated in independent samples (P51.131024; OR 51.20). The risk haplotype involves four amino acid substitutions, all in SLC16A11; it is present with a frequency of $50 \%$ in samples of Native Americans and $10 \%$ in East Asia, but it is rare in European and African samples. The expression of SLC16A11 in heterologous cells alters lipid metabolism and most cannot cause an increase in intracellular triacylglycerol levels. Despite the fact that type 2 diabetes had been well studied through genome-wide association studies in 
other populations, the analysis in Mexican and Latin American individuals identified a gene for type 2 diabetes with a possible role in triacylglycerol SLC 6A11. ${ }^{20}$

Rusu et al., detected 18 genetic variants that encompassed the main genes associated with T2DM. ${ }^{21}$ In this study it was shown that in the Mexican population these variants are in strong imbalance and are associated with a $30 \%$ increase in the risk of T2DM. The credible set includes 12 SNPs without coding encompassing SLC16A11 and SLC16A13, a silent coding SNP in SLC16A13 and the four silent coding SNPs and one wrong direction in SLC16A11. Among these, three non-coding variants proximal to the transcription initiation site SLC16A11 (rs77086571 and rs74577409 in the proximal promoter region SLC16A11 and rs2292351 in 50 UTR) are classified as the most probable causal variants, with a collective posterior probability of $39 \%$, whereas the wrong sense of variants in SLC16A11 show a collective posterior probability of $29 \% .^{21}$

It has been identified that at the time of diagnosis, young people had at least one diabetic relative per direct line. There is a strong hereditary factor associated, probably of multigenic origin, to T2DM. Studies in monozygotic twins have found that if one of them develops T2DM the other twin has $90 \%$ chance of suffering it. In the case of parents if one of them is diabetic, the child has a $40 \%$ chance and this increases up to $70 \%$ if both suffer from it. ${ }^{22}$

\section{Perinatal factors}

About the perinatal factors, it is known that the prevalence of diabetes in children of healthy mothers was $1.4 \%$, in case the mother was prediabetic it increased to $8.6 \%$ and $45.5 \%$ if the mother had gestational diabetes. In another study conducted in the Pima Indians of Arizona, during 1987 and 1996, it was found that $70 \%$ of individuals aged 25 to 34 years old who were exposed to a hyperglycemic intrauterine environment had Type 2 Diabetes. ${ }^{10,19,23}$ It has been studied that those patients with a history of low birth weight, cephalic perimeter less than normal, or macrosomic products have a marked decrease in $\beta$ cells during adulthood. ${ }^{9}$ On the other hand, exclusive breastfeeding during the first 6 months of life reduces the risk of suffering both infectious and non-infectious diseases, particularly in the case of diabetes and hypertension. ${ }^{24}$

\section{EPIDEMIOLOGY}

In 2017, the International Diabetes Federation (IDF) reported that the incidence of T2DM in children and adolescents is increasing in some countries, although data are scarce. Multiple studies conducted in the United States and various countries in Europe and Asia, confirm that the prevalence and incidence of T2DM have increased in children under 19 years old. According to estimates made by the American Diabetes Association, the prevalence of T2DM in children under 20 will quadruple in the next 40 years.
It was Chiumello who, in the $70 \mathrm{~s}$, began to talk about diabetes and hyperinsulinism in obese children. At the end of the 20th century, Wei et al., found that T2DM is the main cause of diabetes in Taiwanese children and young people. ${ }^{4}$ Between the years of 1976 and 1995, Japan reported an incidence of 0.2 to 7.3 per 100,000 people. In the group of 13 to 15 years old, the incidence was 13.9 per 100,000 people; and for $200580 \%$ of the new cases corresponded to T2DM.25 In the United States, Pima Indians showed an increase of $54 \%$ between the years of 1988 and 1996; the group aged between 15 and 19 years old was the most affected. ${ }^{9,10}$ In Latin America, there are still no official databases to demonstrate the magnitude of the problem in this age group. ${ }^{1,3,26}$

According to recent research, the prevalence of T2DM in American adolescents is 12 per 100,000; whereas in Europe the prevalence decreases to 2.5 per 100,000 adolescents. ${ }^{27,28}$ It also highlights that the prevalence rises to 22.3 per 1000 if it is an ethnic group such as African-Americans, Hispanics, Asians, and Native American Indians. ${ }^{29}$ In Mexico, the National Survey on Health and Nutrition (ENSANUT) 2012 included the review of previous diagnoses of Diabetes in adolescents. The $0.7 \%$ reported having been diagnosed with Diabetes, with a higher percentage in women $(0.8 \%)$ than in men $(0.6 \%) .{ }^{30}$ The group with the highest prevalence corresponded to the group between 16 and 19 years; although it is not specified what proportion corresponds to Type 1 Diabetes Mellitus (T1DM) of Type 2 Diabetes. ${ }^{30,31}$

Obesity and overweight are causes associated with T2DM. It has been observed that $25 \%$ of children and $21 \%$ of adolescents who had glucose intolerance had some serious degree of obesity regardless of their ethnic origin. ${ }^{5}$ With respect to age and sex, Nadeau et al., in 2016, reported that the incidence in the United States was 5,000 new cases per year and that it increases between 15 and 18 years old; being $60 \%$ more frequent in women than in men. ${ }^{28}$ This is very close to what was found by ManriqueHurtado et al., who reports that $59 \%$ of cases of Type 2 Diabetes corresponded to females, with an average age of 14.3 years. ${ }^{19}$

According to data obtained from the National Epidemiological Surveillance System in Type 2 Diabetes, in Mexico, by 2018, there have been registered 15,679 cases of T2DM in children under 19 years old, affecting women more frequently. ${ }^{32}$

\section{PHYSIOPATHOLOGY OF T2DM IN ADOLESCENTS}

T2DM is a multifactorial disease resulting from genetic and environmental interactions. It is known that those individuals who have relatives with a history of insulin resistance or hyperinsulinemia are more likely to develop T2DM; 333,34 however genetic factors are not in themselves, sufficient cause for their development.

Excessive visceral and peripheral adipose tissue produces insulin resistance in addition to a progressive loss of pancreatic $\beta$-cell function. ${ }^{35}$ Insulin resistance plays an important role in its 
development. The evidence shows that it occurs 10 to 20 years before the onset of the disease, which is why it is considered the best predictor for the development of Type 2 Diabetes. ${ }^{36}$ The sustained increase in the demand of $\beta$ cells for insulin hypersecretion has a decisive influence on their progressive failure. $9,11,35$

The relationship between insulin sensitivity and insulin secretion is described by a hyperbolic function, which implies that a feedback loop regulates the interaction between the $\beta$ cells and the peripheral tissue. Therefore, when insulin sensitivity decreases, insulin secretion increases so that glucose tolerance remains normal. This balance is described quantitatively by the "disposition index" (DI). The alteration of this system leads, in turn, to a loss of $\beta$ cells and consequently to the appearance of T2DM. In fact, it has been found that at the time of diagnosis, about $80 \%$ of the functions of the $\beta$ cells is reduced or has been totally lost. These data suggest that the presence of a pre-existing risk of $\beta$-cell dysfunction in obese adolescents may be the basis for the development of glucose intolerance and possibly of T2DM in obese young people with normal glucose tolerance. ${ }^{20}$

Puberty is a relevant factor for the appearance of T2DM in adolescents. It is known that growth hormone has an antagonistic effect on insulin, causing an effect of resistance to it. This would explain why the average age of diagnosis is between 14 and 16 years old. ${ }^{27}$ Manrique-Hurtado et al., reported that $68 \%$ of the registered cases were in a Tanner IV and $\mathrm{V}$ stage. ${ }^{19}$ Other studies conducted to measure insulin resistance in different age groups show that the rate of glucose decrease by insulin is $30 \%$ lower in adolescents in stage Tanner II and IV, compared with pre-pubescents or young adults, it is also associated with obesity and polycystic ovarian syndrome. $^{34,37}$

\section{CLINICAL PRESENTATION}

As a rule, most cases are asymptomatic and the diagnosis is established by performing routine examinations with abnormal results. ${ }^{35,38,39}$ The average age for diagnosis is $13.5-14.5$ years old and almost always begins at the age of 10 with a predominance in females. ${ }^{3,7,35}$ The age and the use of ReninAngiotensin-Aldosterone System Inhibitors, served as adverse factors for the development of complications, in addition to having 6.15 times more risk of suffering a vascular disease, than T1DM and controls. ${ }^{25}$

According to Calero-Bernal and Varela-Aguilar, the clinical spectrum has multiple presentations, from an asymptomatic non-ketotic glycosuria, mild polyuria, polydipsia without weight loss and it has even been detected that $6 \%$ of cases begin with a ketoacidosis. ${ }^{25}$ In very rare cases, T2DM is manifested with a hyperosmolar hyperglycemic coma, which is why this type of presentation can confuse the clinician. In many cases, the distinction between T1DM and T2DM is not possible until months later, when insulin requirements decrease and a noninsulin-dependent course develops without depending on insulin to survive. .1,38,40 $^{1}$

It is known that $90 \%$ of adolescents diagnosed with type 2 diabetes present acanthosis nigricans, hyperpigmented lesions with a velvety characteristic predominantly in areas of folds such as the neck, armpits or inguinal folds ${ }^{41}$ frequently associated with hyperinsulinemia and insulin resistance. ${ }^{12,42,43}$ A study conducted in Mexico by Portillo Pineda, et al., in 2011, described that of a sample of 146 children and adolescents, $47.9 \%$ were obese and $47.3 \%$ had typical insulin resistance lesions. ${ }^{43}$ In Paraguay in 2013, Venanzo-Vera and Ramírez found that from the studied obese children, $12 \%$ had insulin resistance, with an average of HOMA (Homeostasis Model Assessment or Model of Determination of Homeostasis for determination of insulin resistance) of 4.23. ${ }^{15}$ In 2015, Caballero-Noguez, et al., reported that of a total of 805 children between 5 and 11 years old, $31.1 \%$ were overweight or obese and $11.3 \%$ had acanthosis nigricans. ${ }^{14}$

In the clinical record we can also find a history of gestational diabetes, low birth weight and macrosomia. ${ }^{7,44,45}$ From 74 to $100 \%$ of the cases have one or more diabetic relatives of first or second degree. ${ }^{42}$ On the other hand, $30 \%$ of adolescents with Polycystic Ovarian Syndrome had signs of glucose intolerance and $4 \%$ of them had T2DM. ${ }^{7,33}$

According to Eppens et al., young people with T2DM have significantly higher rates of microalbuminuria and hypertension than their peers with T1DM, despite a shorter duration of diabetes and lower HbA1C. ${ }^{45}$ Also, Dart et al., conducted a study in 3,063 young people between 1 and 18 years old. From the whole sample, 342 corresponded to T2DM; 1,011 to T1DM and 1,710 control young non-diabetic in a period of 20 years. The results reported that at 5 years old, neurological and renal complications began to appear, while severe complications such as blindness, dialysis or amputation began after 10 years after being diagnosed. However, cardiovascular and cerebrovascular complications were rare and there was no significant difference in retinopathy. ${ }^{25}$

\section{DIAGNOSTIC CRITERIA}

Accurate diagnosis is vital as treatment regimens, educational approaches, dietary advice and outcomes differ markedly among patients with T1DM and T2DM. ${ }^{3}$ The timely detection of T2DM can be a challenge for health personnel and it is even more difficult because it is common to find overweight and obesity in individuals with T1DM. In addition, characteristic lesions of insulin resistance have been identified in these patients.

NOM-015-SSA02-2010 for the prevention and treatment of diabetes and the Clinical Practice Guideline for the Treatment of Type 2 Diabetes Mellitus in the first level of care published in 2017; they indicate that the detection of prediabetes and T2DM should be performed in the general population starting at 20 years old or at the beginning of puberty if they have one or more 
of the following factors: overweight, abdominal obesity, morbid obesity, be of an ethnic group with a genetic predisposition, have relatives of first or second degree with a diagnosis of T2DM, have had extremely low weight or high birth weight or during pregnancy the mother has taken Gestational Diabetes, this must be done every three years. ${ }^{45}$ These same criteria were established in the ADA guide in 2019. ${ }^{38-40,45}$

The diagnosis of prediabetes is established when the fasting plasma glucose (FPG) is equal to or greater than $100 \mathrm{mg} / \mathrm{dl}$ and less than or equal to $125 \mathrm{mg} / \mathrm{dl}$ and/or when the glucose 2 hours after oral loading (2-h PG) of $75 \mathrm{~g}$ of anhydrous glucose is equal or greater at $140 \mathrm{mg} / \mathrm{dl}$ and less than or equal to $199 \mathrm{mg} / \mathrm{dl}$. In the case of Diabetes, the criteria contained in Table 1 must be met. $^{38,40,45}$

It should be noted that the recommended studies for diagnosis should be fasting plasma glucose (FPG), 2-hour plasma glucose ( $2 \mathrm{~h} \mathrm{PG}$ ) after an oral glucose tolerance test of $75 \mathrm{~g}$ (PTOG) or the criteria of Glycosylated hemoglobin (HbA1C). ${ }^{38,45}$ Numerous studies have confirmed that, compared with the cutoff points of GPA and HbA1C, the PG value of $2 \mathrm{~h}$ diagnoses more people with diabetes. ${ }^{38}$ However, they are all equally suitable for diagnostic tests. If there are doubts about the diagnosis, it is necessary to perform a second test to confirm the diagnosis. The ADA recommends performing the same type of test, with a different blood sample as soon as possible since there is a greater likelihood of concurrence. ${ }^{38}$

Table 1 Diagnostic criteria for T2DM according to ADA 2019 NOM 015-SSA2-2010

\begin{tabular}{|c|c|}
\hline ADA Diagnostic Criteria & $\begin{array}{l}\text { Diagnostic Criteria NOM- } \\
\text { 015-SSA2-2010 }\end{array}$ \\
\hline $\mathrm{FPG} \geq 126 \mathrm{mg} / \mathrm{dl}(7 \mathrm{mmol} / \mathrm{mol})$ & $\begin{array}{l}\mathrm{FPG} \geq 125 \mathrm{mg} / \mathrm{dl} \quad(6.8 \\
\mathrm{mmol} / \mathrm{mol})\end{array}$ \\
\hline $\begin{array}{l}\text { 2-h PG } \geq 200 \mathrm{mg} / \mathrm{dL}(11.1 \\
\text { mmol/L) during OGTT. The test } \\
\text { should be performed as } \\
\text { described by the WHO, using a } \\
\text { glucose load containing the } \\
\text { equivalent of } 75-\mathrm{g} \text { anhydrous } \\
\text { glucose dissolved in water. }\end{array}$ & $\begin{array}{l}2-\mathrm{h} P G \geq 200 \mathrm{mg} / \mathrm{dl}(11.1 \\
\mathrm{mmol} / \mathrm{mol}) \text { at } 2 \mathrm{~h} \text { after an oral } \\
\text { load of } 75 \mathrm{~g} \text { of anhydrous } \\
\text { glucose dissolved in water }\end{array}$ \\
\hline $\begin{array}{l}\text { A1C } \geq 6.5 \% \text { ( } 48 \mathrm{mmol} / \mathrm{mol}) \text {. } \\
\text { The test should be performed in } \\
\text { a laboratory using a method } \\
\text { that is NGSP certified and } \\
\text { standardized to the DCCT } \\
\text { assay. }\end{array}$ & -- \\
\hline $\begin{array}{l}\text { In a patient with classic } \\
\text { symptoms of hyperglycemia or } \\
\text { hyperglycemic crisis, a random } \\
\text { plasma glucose } 200 \mathrm{mg} / \mathrm{dL} \\
\text { (11.1 mmol/L). }\end{array}$ & -- \\
\hline
\end{tabular}

Source: own elaboration with information from Standards of Diabetes Care ADA 2019, NOM-015-SSA02-2010 for the prevention and treatment of diabetes. ${ }^{3,45}$

\section{TREATMENT}

The treatment depends on three well-established goals: changes in lifestyle, glycemic control and control of comorbidities. ${ }^{3}$

Within the lifestyle, the patient must achieve: 1) reducing the BMI; 2) encourage physical activity for at least 60 minutes a day; 3) fasting and postprandial glycemic control by the same patient; 4) changes in diet with the reduction of caloric and carbohydrate intake; 5) adherence to treatment through diabetes education for both the individual and the family; and 6) control of tobacco and alcohol. ${ }^{38,40,45}$ In all cases, changes in lifestyle must be included. The goal is to achieve an HbA1C of less than $7 \%$ and in some cases it is necessary to reduce HbA1C lower than $6.5 \% .^{38}$

The pharmacological treatment is limited to two medications: metformin and insulin. Depending on the condition of the patient, the type of treatment will be determined. If the patient is metabolically stable, the ideal is to start with metformin 500$1,000 \mathrm{mg}$ per day with an assessment every two weeks. ${ }^{40}$ In those patients who debuted with ketosis / ketoacidosis / ketonuria, the use of insulin is necessary until glucose levels are normalized. Once the goal is obtained, the subsequent control will be with metformin. The patient must be strictly monitored to avoid hypoglycemia. ${ }^{38-40}$

The goal of the initial treatment is to achieve an HbA1c lower than $7.0 \%$ (53 mmol / mol) and, in some situations, <6.5\% (47.5 mmol / mol). This can almost always be achieved with Metformin and basal insulin, alone or in combination. At a longterm, if the patient does not reach the target HbA1c of $<7.0 \%$ (53 mmol / mol) or $<6.5 \%$ (47.5 mmol / mol) within 4 months in monotherapy with metformin, the addition of basal insulin should be considered. If the goal is not met with the combination of metformin and basal (up to $1.5 \mathrm{U} / \mathrm{kg} /$ day), the start of prandial insulin should be considered, with a titration that reaches the target $\mathrm{HbA} 1 \mathrm{c}<7.0 \%(53 \mathrm{mmol} / \mathrm{mol})$ or $<6.5 \%(47.5$ $\mathrm{mmol} / \mathrm{mol}){ }^{3,38-40}$

As previously mentioned, the use of other oral hypoglycemic agents such as sulfonylureas, which have demonstrated their effectiveness in adults, in young people with T2DM could be beneficial, however there are limited studies on their use. These agents have not been specifically studied in young adults between 18 and 25 years old, but their safety and effectiveness are presumed to be similar to those reported for older adults. ${ }^{4}$

The comorbidities include: hypertension, dyslipidemia, nephropathy, sleep disorders, and hepatic steatosis. In general, they are present at the time of diagnosis, which is why a complete examination of the patient should be performed, including: blood pressure measurement, fundus examination, 24-hour urine albumin / creatinine measurement, full panel of blood lipids. Other associated diseases are: polycystic ovarian syndrome, obesity, sleep apnea, fatty liver among others, which must be treated to avoid future complications. ${ }^{38-40,45}$

\section{CONCLUSION}


As previously mentioned, T2DM in children and adolescents is a pathology that is not well diagnosed, but frequent. This may be due to the few signs and symptoms reported by patients or their mothers and in many cases the diagnosis may go unnoticed by the doctor; in many others it can get confused with T1DM which is more common in these ages. That is why screening in overweight or obese subjects is essential for early detection and timely treatment.

It cannot be denied that the lifestyle of children and adolescents has changed considerably over the last few years. The increase in the prevalence of overweight and obesity, together with sedentary lifestyle and poor diet are daily situations and elements that should be closely monitored in order to ensure health in this population. To continue with this behavior, the outlook that Mexican health system and the population in general face is serious, since in the long run it will have an impact on the potential life years and will increase the years of disability in these adults.

\section{REFERENCES}

1. International Diabetes Federation. IDF Diabetes Atlas [Internet]. $8^{\circ}$ Edición. Bélgica. Edit. International Diabetes Federation, 2017 [Cited april 04, 2019]. Available from: https://www.idf.org/ouractivities/advocacy-awareness/resources-and-tools/134:idf-diabetesatlas-8th-edition.html

2. World Health Organization [Internet]. Suiza: WHO [Actualization: November 2018, Cited April 3, 2019]. Diabetes. Qué es la Diabetes. Available from: http://www.who.int/diabetes/action_online/basics/es/index2.html

3. American Diabetes Association. Standard of medical care in diabetes. Diabetes Care [Internet] 2019 [Cited August 08, 2018]. 40(1): 4-128. Available from: http://fmdiabetes.org/ada/

4. Wei JN, Sung FC, Lin CC, Lin RS, Chiang CC, Chuang LM. National surveillance for type 2 diabetes mellitus in Taiwanese children. JAMA. 2003; 290(10):1345-50.

5. D 'adamo E, Caprio S. Type 2 Diabetes in Youth: Epidemiology and Pathophysiology. Diabetes Care. 2011; 34(2):161-5.

6. World Health Organization [Internet]. Suiza: WHO [Actualization: February 2018, Cited April 3, 2019]. Obesidad y sobrepeso. Datos y cifras. Available from: https://www.who.int/es/news-room/factsheets/detail/obesity-and-overweight

7. Frenk-Baron P, Márquez E. Diabetes Mellitus Tipo 2 En Niños Y Adolescentes. Med. Int. Mex. 2010; 26(1):36-47.

8. Arroyo-López P, Carrete-Lucero L. Alcance de las acciones para prevenir el sobrepeso y la obesidad en adolescentes. El caso de las escuelas públicas mexicanas. Rev. Gerenc. Polít. Salud. 2015; 14(28): $142-68$.

9. Cambizaca-Mora G del P, Castañeda-Abascal I, Sanabria G. Sobrepeso, obesidad y diabetes mellitus 2 en adolescentes de América Latina en 2000 - 2010. Rev. Cuba Med. Gen. e Integr. 2015; 31(2):217-31.

10. Urquidez-Romero R, Esparza-Romero J, Valencia ME. Interacción Entre Genética Y Estilo De Vida En El Desarrollo De La Diabetes Mellitus
Tipo 2: El Estudio En Los Indios Pima. Rev. Cienc. Biológ. Salud. 2015; 17(1):40-6.

11. Calero Bernal ML, Varela Aguilar JM. Infant-juvenile type 2 diabetes. Rev. Clin. Esp. 2018; 218(7):372-381.

12. Dávila-Torres J, González-Izquierdo JJ, Barrera-Cruz A. Panorama de la obesidad en México. Rev. Med. Inst. Mex. Seguro Soc. 2015; 53(2):2409.

13. Medina-Fernández IA, Medina-Fernández JA, Candila-Celis JA, YamSosa AV. Estado nutricional en adolescentes con historia familiar de diabetes tipo 2 de una zona suburbana. RqR. 2018; 6(1):47-59.

14. Caballero Noguez B, Cardoso Gómez MA, Méndez Durán A, González Carmona A, Martínez Jiménez CFY, Zamudio Sánchez D. Prevalencia de sobrepeso y obesidad relacionada con acantosis nigricans en niños de 8 a 12 años de edad de escuelas públicas de una comunidad urbano marginal del Estado de México. Gac. Med. Bilbao. 2016; 113(1): 8-14.

15. Venanzo Vera M, Ramírez L. Resistencia a la insulina en niños y adolescentes con obesidad de Asunción, Paraguay. Rev. Salud Pública Parag. 2013; 3(1): 23-9.

16. World Health Organization [Internet]. Suiza: WHO [Actualization: February 2016, Cited March 07, 2019]. Estrategia mundial sobre régimen alimentario, actividad física y salud. Actividad física. Available from: https://www.who.int/dietphysicalactivity/pa/es/

17. Saucedo-Molina T de J, Rodríguez Jiménez J, Oliva Macías LA, Villarreal Castillo M, León Hernández RC, Fernández Cortés TL. Relación entre el índice de masa corporal, la actividad física y los tiempos de comida en adolescentes Mexicanos. Nutr. Hosp. 2015; 32(3):1082-90.

18. Bonvecchio-Arenas A, González W, Fernández-Gaxiola AC. Alimentación en las diferentes etapas de la vida. Adolescentes de 13 a 18 años. En: Bonvecchio- Arenas A, González A, Fernández-Gaxiola AC, Plazas-Belausteguigoitia M, Kaufer-Horwitz M, Pérez-Lizaur AB, Rivera-Dommarco JB. Guías alimentarias y de actividad física en contexto de sobrepeso y obesidad en la población mexicana. Documento de postura. México: Intersistemas; 2015; p. 17-63.

19. Manrique-Hurtado H, Aro-Guardia P, Pinto-Valdivia M. Diabetes tipo 2 en niños. Serie de casos. Rev. Med. Hered. 2015; 26:5-9.

20. Williams AL, Jacobs SBR, Moreno-Macías H, Huerta-Chagoya A, Churchhouse C, Márquez-Luna C, et al. Sequence variants in SLC16A11 are a common risk factor for type 2 diabetes in Mexico. Nature. 2014; 506:97-112.

21. Rusu V, Hoch E, Mercader JM, Florez JC, Jacobs SBR, Lander ES, et al. Type 2 Diabetes Variants Disrupt Function of SLC16A11 through Two Distinct Mechanisms. Cell. 2017; 170:199-212.

22. Wiebe JC, Wägner AM, Novoa-Mogollón FJ. Genética de la diabetes mellitus. Nefrología. 2011; 2(1):1-119.

23. Martínez-Espinoza A. Características Familiares y exceso de peso en escolares mexicanos en 2012. Cartas al Editor. Rev. Salud Publica. Mex. 2012; 60(1):1-2.

24. Forouhi NG, Wareham NJ. Epidemiology of diabetes. Medicine. 2014; 42(12):698-702

25. Dart AB, Martens PJ, Rigatto C, Brownell MD, Dean HJ, Sellers EA. Earlier onset of complications in youth with type 2 diabetes. Diabetes Care. 2014; 37(2):436-43. 
26. Dabelea D, Stafford JM, Mayer-Davis EJ, D’Agostino RJ, Dolan L, Imperatore G, et al. Association of Type 1 Diabetes vs Type 2 Diabetes Diagnosed During Childhood and Adolescence with Complications During Teenage Years and Young Adulthood. JAMA. 2017; 317(8):825-35.

27. Nadeau KJ, Anderson BJ, Berg EG, Chiang JL, Chou H, Copeland KC, et al. Youth-onset type 2 diabetes consensus report: Current status, challenges, and priorities. Diabetes Care. 2016; 39(9):1635-42.

28. Martorell R. La diabetes y los mexicanos: ¿Por qué están vinculados? Prev. Chronic Dis. 2005; 2(1):1-6.

29. Encuesta Nacional de Salud y Nutrición (ENSANUT). Encuesta Nacional de Salud y Nutrición Resultados finales 2012. México. Instituto Nacional de Salud Pública. 2012.

30. Encuesta Nacional de Salud y Nutrición (ENSANUT). Encuesta Nacional de Salud y Nutrición de Medio Camino 2016. Informe final de resultados. México. Instituto Nacional de Salud Pública. 2017.

31. Dirección General de Epidemiología (DGE). Sistema Nacional de Vigilancia Epidemiológica. Diabetes Mellitus Tipo 2. Sistema de Información en Enfermedades Crónicas (SIC) Diabetes Mellitus. 2018.

32. Schnell M, Dominguez ZA, Carrera C. Aspectos genéticos, clínicos y fisiopatológicos del Síndrome Metabólico. An. Venez. Nutr. 2007; 20(2):92-8.

33. Licea Puig ME, Bustamante Teijido M, Lemane Pérez M. Diabetes tipo 2 en niños y adolescentes: aspectos clínico-epidemiológicos, patogénicos y terapéuticos. Rev. Cubana Endocrinol. 2008; 19(1):1-21.

34. Reinehr T. Type 2 diabetes mellitus in children and adolescents. WJD. 2013; 4(6):270-81.

35. Peplies J, Jiménez-Pavón D, Savva SC, Buck C, Günther K, Fraterman $\mathrm{A}$, et al. Percentiles of fasting serum insulin, glucose, HbAlc and HOMA-IR in pre-pubertal normal weight European children from the IDEFICS cohort. Int. J. Obes. (Lond). 2014; 38: S39-47.

36. Riveros Sasaki K, Alderete Peralta V, Sánchez Bernal S. Frecuencia de elementos del Síndrome Metabólico en adolescentes de un colegio público. Pediatr. (Asunción) 2012; 39(1):13-9.

37. American Academy of Pediatrics. Management of Type 2 Diabetes Mellitus in Children and Adolescents. Technical Report. Pediatrics. 2013; 13(2):1-19.

38. Zeitler P, Arslanian S, Fu J, Pinhas-Hamiel O, Reinehr T, Tandon N, et al. ISPAD Clinical Practice Consensus Guidelines 2018: Type 2 diabetes mellitus in youth. Pediatr. Diabetes. 2018; 19(7):28-46.

39. Arenas R. Enfermedades del Metabolismo y de Depósito. In: Dermatología. 5. México: McGraw-Hill; 2013. p. 183-4.

40. Libman IM. Epidemiología de la diabetes mellitus en la infancia y adolescencia: tipo 1, tipo 2 y idiabetes "doble"? Rev. Argent. Endocrinol. Metab. 2009; 46(3):22-36.

41. Portillo Pineda A, Nuñez Olivares MA, Figueroa Nuñez B, Gómez Alonso C, Mejía Rodríguez O. Identificación de Acantosis nigricans y su relación con obesidad y resistencia a la insulina en niños y adolescentes en una Unidad de Medicina Familiar en Michoacán, México. Rev. Aten. Fam. 2011; 18(2):31-4.

42. Violante Ortiz RM. Obesidad y diabetes tipo 2 en el niño. Una nueva epidemia. Rev. Endocrinol. Nutr. 2001; 9(2):103-6.
43. Secretaría de Salud. NOM-015-SSA2-2010, Para la prevención, tratamiento y control de la Diabetes Mellitus. [Internet]. Diario Oficial de la Federación [Actualization November 23, 2010, Cited October 12, 2018] Available from: http://www.hgm.salud.gob.mx/descargas/pdf/dirgral/marco_juridico/no rmas/nom_14.pdf

44. Martínez-Balisa A, Maldonado-Hernández J, López-Alarcón M. Métodos diagnósticos de la resistencia a la insulina en la población pediátrica. Bol. Med. Hosp. Infant. Mex. 2011; 68(5):397-404.

45. Eppens MC, Craig ME, Cusumano J, Hing S, Chan AKF, Howard NJ, et al. Prevalence of diabetes complications in adolescents with type 2 compared with type 1 diabetes. Diabetes Care. 2006; 29(6):1300-6. 